\title{
A Study on Emotional Quotient Among new Generation Employees
}

\author{
Mr. S. Maheshwaran ${ }^{1}$, Dr. K. Soniya ${ }^{2}$, Dr. S. Krishnaraj ${ }^{3}$ \\ ${ }^{1}$ Research Scholar, ${ }^{2,3}$ Associate Professor \\ ${ }^{1,3}$ BSMED, Bharathiar University, Coimbatore, Tamil Nadu, India \\ ${ }^{2}$ T. John Institute of Management and Science, Bangalore, Karnataka, India
}

\begin{abstract}
Success in the workplace takes a lot more than education, book knowledge or experience. Organizations and the conscious, achievementoriented managers need a high rate of "Emotional Quotient" to be successful. Emotional Quotient is the ability to identify and manage personal emotions and the emotions of others. Emotional Quotient (EQ) matters just as much as intellectual ability (IQ). In the employment field, work pressure, anxiety, employee's stress, agitation, depression or irritability all are related to the various factors of emotional intelligence. All these emotional intelligence symptoms could harm employee's performance. It can direct either a higher or lower level of morale, which will ultimately impact employee's performance in a positive or negative way. The main question of the study is to analyze the emotional intelligence according to new generations in banking and IT Field.
\end{abstract}

Keyword: Knowledge, Emotional Intelligence , Emotional Quotient

\section{INTRODUCTION}

\section{Emotional Intelligence}

Goleman'smodel, EI can be organised into four dimensions representing the recognition of emotions in ourselves and in others, as well as the regulation of emotions in ourselves and in others. Each dimension consists of a set of emotional competencies that people must process to fulfil that dimension of emotional intelligence.

Self-Awareness---Self-awareness refers to having a deep understanding of one's own emotions as well as strengths, weaknesses, values, and motives. Self aware people are in touch with their feeling and know what feels right to them. In other words, they effectively recognize their intuition or gut instincts.

Self-Management--This represents how well we control or redirect our internal states, impulse, and resource. it includes keeping disruptive implies in check, displaying honesty and integrity, being flexible in times of change, maintain the drive to perform well and seize opportunities, and remaining optimistic even after failure. Self management involves an inner conversation that guides our behaviour.

Emotional intelligence is the ability to perceive and express emotion, simulate emotion in thought, understand and reason with emotion, and regulate emotion in oneself and others. Emotional Intelligence represents a set of competencies that allow us to perceive, understand, and regulate emotions in ourselves and in others. These emotional competencies are learned capabilities based on emotional intelligence that lead to superior performance.

EI model developed by psychologist and journalist Daniel Goleman and his colleagues. According to

Social-Awareness-- social awareness in mainly about empathy--having understanding sensitivity to the feelings, thoughts, and situation of others. This includes cognitively understanding another person's situational circumstances as well as actually experiencing in other person's feelings. by being empathic, people are also able to know a customer's needs and expectations, even when unstated. Social awareness extends beyond empathy for other individuals; it also includes being organisationally aware, such as sensing office politics and understanding social networks 


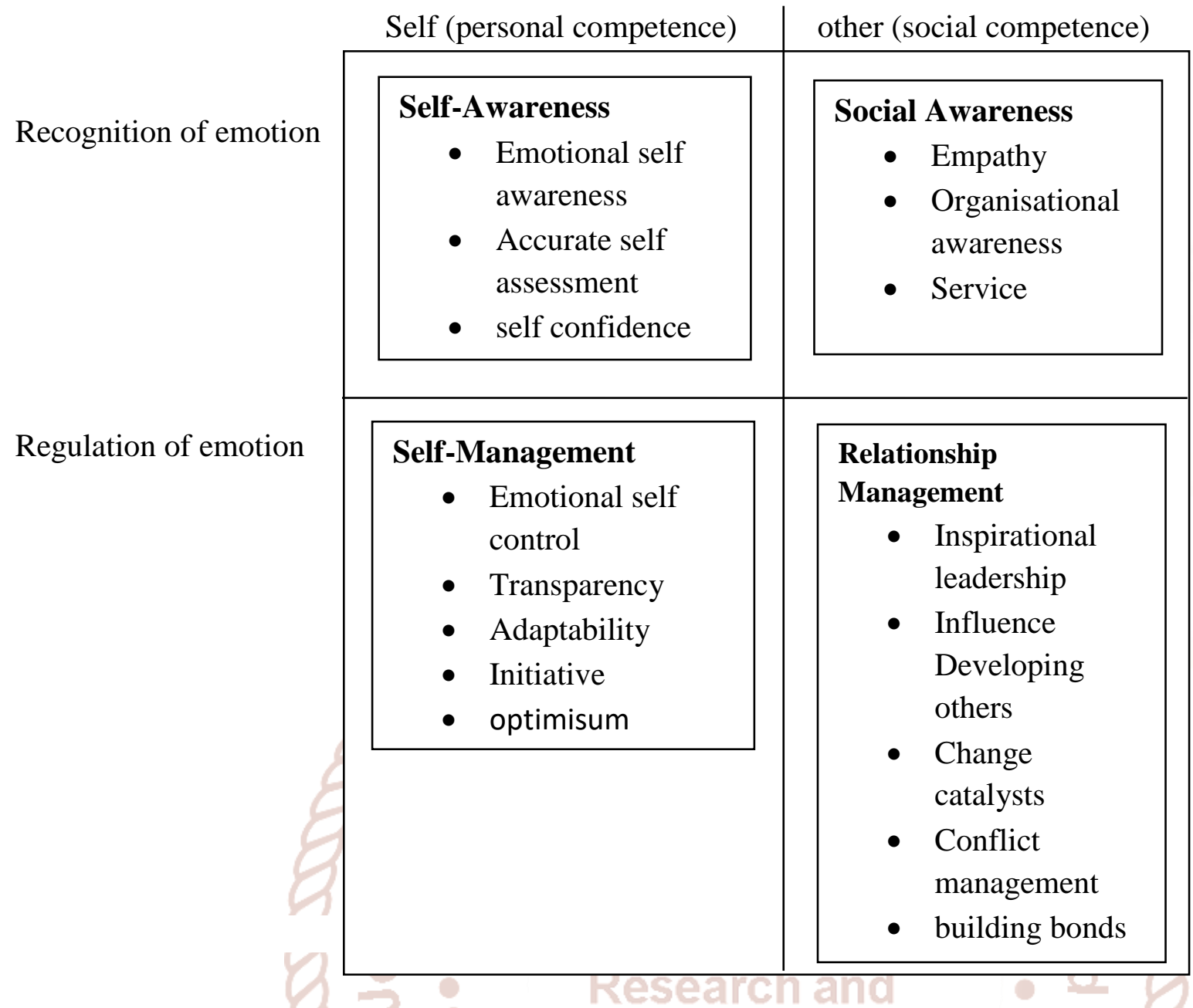

Emotional intelligence can be defined as the ability to monitor one's own and other people's emotions, to discriminate between different emotions and label them appropriately and to use emotional information to guide thinking and behaviour. However, substantial disagreement exists regarding the definition of EI, with respect to both terminology and operationalizations. Currently, there are three main models of EI:
1. Ability model

2. Mixed model (usually subsumed under trait EI)

3. Trait model

Different models of EI have led to the development of various instruments for the assessment of the construct. While some of these measures may overlap, most researchers agree that they tap different constructs.

\begin{tabular}{|c|c|c|}
\hline Dimension & \multicolumn{2}{|c|}{ Model of Emotional Intelligence } \\
\hline & Mixed Model & Ability Model \\
\hline $\begin{array}{c}\text { Conception of } \\
\text { EI }\end{array}$ & $\begin{array}{l}\text { EI viewed as melange of competencies and general } \\
\text { dispositions for adaptive personal functioning and coping } \\
\text { with environmental demands. The construct encompasses } \\
\text { multiple aspects of emotional and personal knowledge } \\
\text { and personal functioning that are rather loosely related to } \\
\text { emotion, including: motivation, personality traits, } \\
\text { temperament, character, and social skills }\end{array}$ & $\begin{array}{l}\text { EI is viewed as a well-defined } \\
\text { and conceptually related set of } \\
\text { cognitive abilities for the } \\
\text { processing of emotional } \\
\text { information and regulating } \\
\text { emotion adaptively }\end{array}$ \\
\hline $\begin{array}{c}\text { Number of } \\
\text { competencies }\end{array}$ & $\begin{array}{l}\text { Anywhere from } 4 \text { to } 2 \text { dozen abilities. These can be } \\
\text { grouped into } 4 \text { core areas: self-awareness, self- } \\
\text { regulation/management, social awareness, relationship } \\
\text { management and social skills (Cherniss\&Goleman, 2001) }\end{array}$ & $\begin{array}{l}4 \text { major } \quad \text { branches: } \\
\text { identification, understanding, } \\
\text { usage, and self-regulation } \\
\text { (Salovey et al., 2000) }\end{array}$ \\
\hline
\end{tabular}


International Journal of Trend in Scientific Research and Development (IJTSRD) ISSN: 2456-6470

\begin{tabular}{|c|l|l|}
\hline $\begin{array}{c}\text { Morphological } \\
\text { structure }\end{array}$ & Nonhierarchical_coligarchic” organisation & $\begin{array}{l}\text { Hierarchical model-from } \\
\text { basic psychological processes } \\
\text { to higher more psychologically } \\
\text { integrated processes }\end{array}$ \\
\hline $\begin{array}{c}\text { Factor } \\
\text { structure }\end{array}$ & $\begin{array}{l}\text { Little empirical data. General factor found for individual } \\
\text { published scales, but little evidence to support claims of } \\
\text { multiple factors (cf. Petrides\&Furnham, 2000) }\end{array}$ & $\begin{array}{l}\text { Inconsistent with 4-branch } \\
\text { model. Exploratory factor } \\
\text { analytic data consistent with } 3 \\
\text { factor models of perception, } \\
\text { understanding, regulation } \\
\text { (Mayer, Caruso, \&Salovey, } \\
\text { 2000; Roberts et al., 2001) }\end{array}$ \\
\hline $\begin{array}{c}\text { Reliability of } \\
\text { scales }\end{array}$ & Satisfactory (Bar-On, 1997; Dawda\& Hart, 2000) & $\begin{array}{l}\text { Low to Moderate (Roberts et } \\
\text { al., 2001); inconsistency among } \\
\text { scoring procedures and low } \\
\text { subtest reliabilities }\end{array}$ \\
\hline $\begin{array}{c}\text { Susceptibility } \\
\text { of items to } \\
\text { response sets }\end{array}$ & $\begin{array}{l}\text { Inconsistent data; some evidence for extreme item } \\
\text { endorsement (Dawda\& Hart, 2000) }\end{array}$ & \begin{tabular}{l} 
Not relevant \\
\hline
\end{tabular} \\
\hline
\end{tabular}

\section{Emotional Quotient}

While it is often misunderstood as intelligence quotient (IQ), Emotional Quotient is different because instead of measuring your general intelligence, it measures your emotional intelligence. Emotional Quotient is the ability to sense, understand and effectively apply the power and acumen of emotions to facilitate high levels of collaboration and productivity. In the business environment, Emotional Quotient is important because it helps you leverage your awareness of emotions for effectiveness in the workplace.

\section{Assessing Of Emotional Quotient}

The TTI Emotional Quotient assessment measures an individual's emotional intelligence with an online questionnaire that is immediately analyzed to produce a report with detailed information about the individual's Emotional Quotient score. The higher the score in the report is, the higher the level of emotional intelligence will be. At any level, the TTI Emotional Quotient report will empower individuals to understand their own EQ so they can avoid making high-risk decisions without understanding how their emotions are influencing their choice. Instead they can make educated, sound decisions with their head, instead of just their heart

The TTI Emotional Quotient report focuses on five areas within interpersonal and intrapersonal intelligence. Intrapersonal intelligence is the ability to understand oneself, while interpersonal intelligence is the ability to understand others.
While it is often misunderstood as intelligence quotient (IQ), Emotional Quotient is different because instead of measuring your general intelligence, it measures your emotional intelligence. Emotional Quotient is the ability to sense, understand and effectively apply the power and acumen of emotions to facilitate high levels of collaboration and productivity. In the business environment, Emotional Quotient is important because it helps you leverage your awareness of emotions for effectiveness in the workplace.

\section{Measurement}

A person's EQ can be measured using any of various assessments, including one developed by Salovey and Mayer. Some assessments use self-given responses, and others are based on peer-given responses. Although a single test might give some insight into a person's personality and psychological make-up, discovering the true value of EQ and its relationship to and impact on a person's life might take years and multiple studies.

\section{Uses}

Measurements of people's emotional intelligence quotients are used in many settings. The idea is very popular in the corporate world, where many businesses use EQ tests to help their employees determine and measure their emotional responses to various situations. Most such tests are administered with the idea that this factor can be modified or increased, but there is dispute about whether a 
person's emotional intelligence is something he or she is born with or if it can be changed.

\section{Application}

Studies have been done on possible ways that a high or low EQ might affect a person's abilities to perform under pressure, resolve conflict, and cope with challenges. For example, someone who has a low EQ might lack self-confidence and be pessimistic, both of which might affect his or her performance when doing certain tasks. People who are not proponents of the concept believe that things such as confidence, selfesteem and attitude are simply a matter of personality, which cannot be measured or modified. Other studies have linked this measurement to communication skills and other social skills that people possess.

\section{Generations of Employees Traditional Generation}

The Traditional generation is the oldest generation in the workplace, although most are now retired. Also known as the veterans, the Silents, the Silent generation, the matures, the greatest generation, this generation includes individuals born before 1945, and some sources place the earliest birth year to 1922 Members of this generation were influenced by the great depression and World War II among other events and have been described as being conservative and disciplined, as having a sense of obligation, and as observing fiscal restraint (Niemic, 2002). They have been described as liking formality and a top down chain of command, as needing respect, and as preferring to make decisions based on what worked in the past (Kersten, 2002). The National Oceanographic and Atmospheric Association Office of Diversity (2006) characterized members of this generation as the private, silent generation, who believe in paying their dues, for whom their word is their bond, who prefer formality, have a great deal of respect for authority, like social order and who love their things and tend to hoard stuff. Members of this generation have also been characterized as loyal workers, highly dedicated, averse to risk and strongly committed toward teamwork and collaboration. They have also been described as having a high regard for developing communication skills, and as the most affluent elderly population in the U.S., due to their tendency to save and conserve (Jenkins, 2007). At work, they are presumed to show consistency and uniformity, seek out technological advancements, be past-oriented, display command-and-control leadership reminiscent of military operations, and prefer hierarchical organizational structures. They are likely to continue to view horizontal structures in a hierarchical way They are also likely to be stable, detail oriented, thorough, loyal, and hard working, although they may be inept with ambiguity and change, reluctant to buck the system, uncomfortable with conflict, and reticent when they disagree (Zemke et al., 2000).

\section{Baby Boom Generation}

The Baby Boom generation most sources identify Baby Boomers as people born between 1943 and 1965. The U.S. Census Bureau defines Baby Boomers as individuals born between 1946 and 1964. The Baby Boom generation has also been referred to as the "pigin-the-python" (Callanan\&Greenhaus, 2008). This generation is referred to as the Baby Boom, because of the extra seventeen million babies born during that period relative to previous census figures (O'Bannon, 2001). It has had the largest impact on American society due to its size - roughly 78 million- and the period during which it came of age. Boomers witnessed and partook in the political and social turmoil of their time: the Vietnam War, the civil rights riots, the Kennedy and King assassinations, Watergate and the sexual revolution (Bradford, 1963) as well as Woodstock (Adams, 2000) and the freewheeling 60's (Niemiec, 2000). Protesting against power characterized the formative years of many of the individuals now in leadership positions in numerous organizations. Boomers were raised to respect authority figures, but as they witnessed their foibles, learned not to "trust anyone over 30" (Karp, Fuller, $\&$ Sirias, 2002). They grew up in an era of "prosperity and optimism and bolstered by the sense that they are a special generation capable of changing the world, have equated work with self-worth, contribution and personal fulfillment" (p.270.Yang \& Guy, 2006). The oldest Baby Boomers turned 62 in 2008, and as a whole, this generation is now in the mid to late part of their careers. The entirety of this generation will reach the traditional retirement age of 65 within the next 25 years (Callanan\&Greenhaus, 2008).

\section{Generation X}

In a study about the civic engagement of Generation $\mathrm{X}$, the U.S. Census Bureau defined this segment of the population as consisting of individuals born between 1968 and 1979. However, the upper limit of Generation X in some cases has been as high as 1982, while the lower limit has been as low as 1963 (Karp et al., 2002). This generation was also called the baby bust generation, because of its small size relative to 
the generation that preceded it, the Baby Boom generation. The term Generation $X$ spread into popular parlance following the publication of Douglas Coupland's book about a generation of individuals who would come of age at the end of the 20th century. Members of Generation X [Hereinafter Xers] are the children of older boomers, who grew up in a period of financial, familial and societal insecurity. They witnessed their parents get laid off and the decline of the American global power. They grew up with a stagnant job market, corporate downsizing, and limited wage mobility, and are the first individuals predicted to earn less than their parents did. They have grown up in homes where both parents worked, or in single parent household because of high divorce rates, and as such, became latchkey kids forced to fend for themselves (Karp et al., 2002). They were influenced by MTV, AIDS and worldwide competition and are accustomed to receiving instant feedback from playing computer and video games (O'Bannon, 2001). Among the characteristics attributed to Xers, the following appear most often. They aspire more than previous generations to achieve a balance between work and life (Jenkins, 2007; Karp et al, 2002; www.valueoptions.com) they are more independent, autonomous and self-reliant than previous generations (Jenkins, 2007; Zemke et al., 2000) having grown up as latchkey kids. They are not overly loyal to their employers (Bova\&Kroth, 2001; Karp et al, 2002; The National Oceanographic and Atmospheric Association Office of Diversity, 2006) although they have strong feelings of loyalty towards their family and friends (Karp et al., 2002). They value continuous learning and skill development (Bova\&Kroth, 2001). They have strong technical skills (Zemke et al., 2000), are results focused (Crampton\& Hodge, 2006), and are "ruled by a sense of accomplishment and not the clock" (Joyner, 2000). Xers naturally question authority figures and are not intimidated by them (The National Oceanographic and Atmospheric Association Office of Diversity, 2006; Zemke et al., 2000). Money does not necessarily motivate members of this generation, but the absence of money might lead them to lose motivation (Karp et al., 2002). They like to receive feedback (The National Oceanographic and Atmospheric Association Office of Diversity, 2006), are adaptable to change (Zemke et al., 2000) and prefer flexible schedules (Joyner, 2000). They can tolerate work as long as it is fun (Karp et al., 2002). They are entrepreneurial (The National Oceanographic and Atmospheric Association Office of Diversity, 2006), pragmatic (Niemiec, 2002), and creative (The National Oceanographic and Atmospheric Association Office of Diversity, 2006). Although they are individualistic, they may also like teamwork, more so than boomers (Karp et al., 2002).

\section{Generation Y}

The lower limit for Generation Y may be as low as 1978, while the upper limit may be as high as 2002, depending on the source. Members of Generation Y may include individuals born between 1980 and 1999 (Campton \& Hodge, 2006); 1978 and 1995 (The National Oceanographic and Atmospheric Association Office of Diversity, 2006); 1980 and 2002 (Kersten, 2002); and 1978 and 1988 (Martin, 2005). The label associated with this generation is not yet finalized. Current labels include Millenials, Nexters, Generation www, the Digital generation, Generation E, Echo Boomers, N-Gens and the Net Generation. Members of the generation have labeled themselves as the NonNuclear Family generation, the NothingIs-Sacred Generation, the Wannabees, the Feel-Good Generation, Cyberkids, the Do-or-Die Generation, and the Searching-for-an-Identity Generation. This generation has been shaped by parental excesses, computers (Niemiec, 2000), and dramatic technological advances. One of the most frequently reported characteristics of this generation is their comfort with technology (Kersten, 2002). In general, Generation $\mathrm{Y}$ shares many of the characteristics of Xers. They are purported to value team work and collective action (Zemke et al., 2000), embrace diversity (The National Oceanographic and Atmospheric Office of Diversity, 2006), be optimistic (Kersten, 2002), and be adaptable to change (Jenkins, 2007). Furthermore, they seek flexibility (Martin, 2005), are independent, desire a more balanced life (Crampton\& Hodge, 2006), are multi-taskers (The National Oceanographic and Atmospheric Office of Diversity, 2006), and are the most highly educated generation. They also value training (www. valueoptions.com). They have been characterized as demanding (Martin, 2005), and as the most confident generation (Glass, 2007). Like Xers, they are also purported to be entrepreneurial, and as being less process focused (Crampton\& Hodge, 2006).

Overall, this generation of people prefers to communicate through e-mail and text messages rather than actual face-to-face contact. Learning for them is more than just traditional brick and mortar college campuses. They also have access to presentations via 
webinars and online classes. Because children born during this time period have always had constant access to modern technology, such as computers, laptops and cell phones, in their youth, their employment and social life is constantly defined by or required to incorporate updated forms of such types of electronics.

\section{Characteristics of Generation Y}

Generation $\mathrm{Y}$ is thought to be more family-oriented and willing to sacrifice career advancement for a better work/life balance. However, this doesn't mean they aren't achievement-oriented. Generation Y can be confident and ambitious. They are not afraid to question authority, are constantly seeking out new challenges and want meaningful work.

Generation Y people typically want to be part of a team, but at the same time they desire to be in the spotlight. While they value teamwork and seek the input and affirmation of others, they also crave attention, feedback and guidance. Overall, they are loyally committed and want to be included and involved.

Several other characteristics have been found over the years. According to a 2013 poll in the United Kingdom, Generation Y was found to be more openminded than their parents to controversial topics. It's also significantly more likely that Generation Y people don't practice any organized religion than older generations and tend to distrust religious institutions.

\section{Need for the Study}

In particular, this study aims to analyse the emotional quotient among the new generation employees based on

$>$ Social awareness

$>$ Self awareness

$>$ Social skill

$>$ Self management

As emotional stability helps new generation employees to perform well in their organisation, it has become more appropriate to conduct this study.

\section{Review of Literature}

Mayer and Salovey (1989) has first defined emotional intelligence (EI) as "The subset of social intelligence that involves the ability to monitor one's own and others' feelings and emotions, to discriminate among them and to use this information to guide one's thinking and actions" (Salovey, Mayer, 1989: 189).

The Salovey and Mayer Model: Model defines emotional intelligence as the ability to perceive, understand, manage and use emotions to facilitate thinking. It contains four subscales: perceiving emotions, using emotions to simplify thought, understanding and managing emotions (Mayer, Salovey, Caruso, 2000: 396).

It is not new that workplaces have generational differences, but the importance of these differences is new and poses inimitable challenges for organizations worldwide. Today's multigenerational workplaces require that organizations understand and value diversity in order to benefit from it; after all, the need to feel important and respected cuts through all generations. In the current period, employee needs are significantly changing and organizations are in a constant search of motivation. Emotional intelligence is very significant to a multigenerational workplace in that it enhances employee productivity, employee happiness, job satisfaction and leadership proficiency; in addition, it creates mutual employeeemployer relationships which increase employee's commitment to an organization (Njoroge, Yazdanifard, 2014: 34).

In today's workplace, where it's not uncommon to find four or five generations, multiple languages, many ethnicities and races and differences in gender, religion, personalities and values (Gardenswartz, Cherbosque, Rowe, 2008). There's also a more fundamental changes to today's shifts. In past generational changes, new workers tended to adjust their expectations and behavior to the realities of the organizations and workplace. Today's new generations expect the workplace will adjust to them. Emotional intelligence improves the skills leaders need to understand the behaviour of workers and motivation of co-workers with different values and to find the common ground that can build a cohesive.

\subsection{Objectives of the Study}

- To study the Emotional Quotient among the new generation employees of Banking and IT sector.

- To analyse the Emotional Quotient of the employees on

$>$ Self awareness

$>$ Social awareness

$>$ Self management

$>$ Social skill 
International Journal of Trend in Scientific Research and Development (IJTSRD) ISSN: 2456-6470

- To study the relationship between the demographic variables and the factors constituting Emotional Quotient.

\section{Research Methodology \\ Research Design: -}

$>$ The research design is descriptive research.

Descriptive research includes surveys and factfinding enquiries of different kinds. The major purpose of descriptive research is description of the state of affairs as it exists at present. In social science and business research we quite often use the term ex post facto research for descriptive research study.

\begin{tabular}{|l|l|}
\hline \multicolumn{1}{|c|}{ Sample size } & \multicolumn{1}{c|}{150 Respondents } \\
\hline $\begin{array}{l}\text { Sampling } \\
\text { technique }\end{array}$ & $\begin{array}{l}\text { Non probability sampling, } \\
\text { Convenience sampling }\end{array}$ \\
\hline Sampling unit & $\begin{array}{l}\text { Employees from the IT \& } \\
\text { Banking sector }\end{array}$ \\
\hline
\end{tabular}

\section{Data Collection}

> Primary Data A sample size of 150 employees from the banking (75) and IT (75) sector were taken for the study and the questionnaire was designed with 40 questions. The selection of 3 banks and 3 IT companies was based on their maximum market share. Responses from the entire sample were analyzed. Questions relevant to each hypothesis were grouped together and their responses were compiled and studied.

Secondary Data Relevant published literature and information available in the relevant books, articles, magazines, research papers and websites were all part of the literature review.

\section{Sampling Design}

Convenience sampling

When population elements are selected for inclusion in the sample based on the ease of access, it can be called convenience sampling

\section{Statistical tools used}

All the responses to the questions from the questionnaire were analyzed. The following statistical techniques were used to analyze the data

\section{Independent Sample ' $t$ ' test}

Limitations of the Study

- A small sample size of 150 employees was taken, inferences cannot be drawn about the population.

- The scope of the project is limited to two industries. So, it cannot be established that the same response will exist throughout all sectors of employees.

- This research is based on the studying of emotional quotient. But, the employee's emotional quotient among new generation employees may change according to time, industry, technology, development, organisational culture and climate.

\section{ANALYSIS AND INTERPRETATIONTABLE: RELATIONSHIP}

\section{BETWEEN GENDER AND SELF AWARENESS}

Null Hypothesis (H0):-

There is no significant difference between gender and self awareness

Alternative Hypothesis (H1):-

There is a significant difference between gender and self awareness

Significant level:- 0.05 or $5 \%$

\begin{tabular}{|c|c|c|c|c|c|c|}
\hline \multicolumn{7}{|c|}{ Independent Samples Test } \\
\hline & & \multicolumn{2}{|c|}{$\begin{array}{l}\text { Levene's Test for } \\
\text { Equality of Variances }\end{array}$} & \multicolumn{3}{|c|}{ t-test for Equality of Means } \\
\hline & & $\mathbf{F}$ & Sig. & $\mathbf{T}$ & Df & Sig. (2-tailed) \\
\hline \multirow{2}{*}{$\begin{array}{l}\text { Average } \\
\text { SA }\end{array}$} & Equal variances assumed & .782 & .378 & -.410 & 147 & .683 \\
\hline & Equal variances not assumed & & & -.414 & 146.779 & .680 \\
\hline
\end{tabular}

The table depicts that $\mathrm{f}$ value for the' $\mathrm{t}$ ' test is .683 , which is higher than the significance level of 0.05 , Hence, the null hypothesis is accepted and, therefore gender does not influence self awareness. 
Null Hypothesis (H0):-

\section{TABLE: RELATIONSHIP BETWEEN AGE AND SOCIAL AWARENESS}

There is no significant difference between age and social awareness

\section{Alternative Hypothesis (H1):-}

There is a significant difference between age and social awareness

Significant level: -0.05 or $5 \%$

\begin{tabular}{|l|c|c|}
\hline \multicolumn{1}{|c|}{ Statement } & F & Sig. \\
\hline sensing when others are feeling down or upset & .184 & .907 \\
\hline Addressing the needs and concerns of others & 2.395 & .071 \\
\hline Alerting others when the harmony within the group is under strain & 2.521 & .060 \\
\hline Taking account of others agendas and priorities when making presentations & 3.101 & .029 \\
\hline Being sensitive to the political undertone in the organisation & 4.912 & .003 \\
\hline Spotting where personality clashes may impact on work performance & 5.266 & .002 \\
\hline Identifying where alliances could be built with other areas & .882 & .452 \\
\hline Appreciating the pressure under which others are operating & .681 & .565 \\
\hline Anticipating customer needs & 3.687 & .013 \\
\hline Generating ideas that others find attractive & 1.267 & .288 \\
\hline
\end{tabular}

Some of the factors have a level of significance which is more than 0.05 level of significance and hence, Null hypothesis is accepted and therefore, it can be interpreted that age does not have an influence on the social awareness of the respondents with regard to feeling down(.907), addressing the needs(.071), alerting others(.060), identifying where alliances could be built(.029), appreciating the pressure(.003), generating ideas(.288).
Some of the factors have a level of significance which is less than 0.05 level of significance and hence, null hypothesis is rejected and therefore it can be interpreted that, age have the influence on the social awareness of the respondents with regard to political undertone(.003), ), spotting where personality clashes(.002), anticipating customer needs(0.013).

\section{TABLE: RELATIONSHIP BETWEEN SELF MANAGEMENT AND YEARS OF EXPERIENCE Null Hypothesis (H0):-}

There is no significant difference between Year of experience and self management

\section{Alternative Hypothesis (H1):-}

There is a significant difference between Year of experience and self management

Significant level: -0.05 or $5 \%$

\begin{tabular}{|l|c|c|}
\hline \multicolumn{1}{|c|}{ Statement } & F & Sig. \\
\hline maintain calm appearances when my situation becomes uncomfortable & .019 & .981 \\
\hline making my action match my words & 1.299 & .276 \\
\hline controlling any potentially emotional outburst & 3.592 & .030 \\
\hline staying openly committed on tasks i do not consider worthwhile & 5.219 & .006 \\
\hline holding back from expressing criticism of others & .194 & .824 \\
\hline adjusting rapidly when the situation changes & 5.429 & .005 \\
\hline tackling obstacles and problems rather than simply complaining about them & 5.980 & .003 \\
\hline initiating action on tasks without needing to be asked & 1.526 & .221 \\
\hline taking advantage of new opportunities in the work place & 1.393 & .252 \\
\hline considering all criticism non-defensively & .177 & .838 \\
\hline
\end{tabular}


Some of the factors have a level of significance which is more than 0.05 level of significance and hence, null hypothesis is accepted and therefore it can be interpreted that experience does not have an influence on the self management with regard to maintain calm appearances (.981), making my action match my words (.276), holding back (.824), initiating action (.221), taking advantage(.252), considering all criticism(.838).

\section{TABLE: RELATIONSHIP BETWEEN EDUCATIONAL QUALIFICATION AND SOCIAL SKILLS} Null hypothesis (H0):-

There is no significant difference between Educational Qualification and social skill

\section{Alternative hypothesis (H1):-}

There is a significant difference between Educational Qualification and social skill

\section{Significant level:- -0.05 or $5 \%$}

\begin{tabular}{|l|c|c|}
\hline \multicolumn{1}{|c|}{ Statement } & F & Sig. \\
\hline Taking the lead whenever there is an opportunity to do so & 3.457 & .018 \\
\hline Working through informal networks to get things done & 2.526 & .060 \\
\hline Influencing the thinking of others ernational J Oulnalle & 1.173 & .322 \\
\hline Presenting ideas in a way that engages others and inspires them to achieve more & 1.104 & .349 \\
\hline Providing feedback which others act on & 3.037 & .031 \\
\hline Supporting others in their learning and development & 3.049 & .031 \\
\hline Communicating clearly and effectively Velonent & .648 & .586 \\
\hline Listening attentively & .828 & .481 \\
\hline Cooperating fully with others to achieve goals & .654 & .582 \\
\hline Handling disagreement and confrontations positively & .693 & .558 \\
\hline
\end{tabular}

Some of the factors have a level of significance which is more than 0.05 level of significance and hence, null hypothesis is accepted therefore it can be interpreted that, education qualification does not have an influence on self management with regards to working through informal networks (.060), taking the lead (.018), influencing the thinking (.322), presenting ideas (.586), listening attentively (.481), cooperating fully(.582), handling disagreement(.558).

Some of the factors have a level of significance which is less than 0.05 level of significance and hence, null hypothesis is rejected and therefore it can be interpreted that, educational qualification does not have an influence on the self management with regard to Providing feedback(.031), Supporting others(.031).

\section{FINDING, SUGGESTIONS\& CONCLUSION}

\section{Findings}

self awareness does not influence Gender of the respondents

Age does not have an influence on the social awareness of the respondents with regard to feeling down(.907), addressing the needs(.071), alerting others(.060), identifying where alliances could be built(.029), appreciating the pressure(.003), generating ideas(.288), taking account of others agendas and priorities(.452).

$>$ Age have the influence on the social awareness of the respondents with regard to political undertone (.003), spotting where personality clashes (.002), anticipating customer needs (0.013).

Experience does not have an influence on the self management with regard to like maintain calm 
appearances(.981), making my action match my words(.276), holding $\operatorname{back}(.824)$, ), initiating action(.221), ), taking advantage(.252), considering all criticism(.838).

$>$ Experience does not have an influence the self management with regard to emotional outburst(.030), tackling obstacles(0.03), adjusting rapidly $(0.05)$

$>$ Education qualification does not have an influence on self management with regards to working through informal networks(.060), taking the lead(.018), influencing the thinking(.322), presenting ideas(.586), listening attentively(.481), ), cooperating fully(.582), handling disagreement(.558).

$>$ Educational qualification does not have an influence on the self management with regard to providing feedback (.031), Supporting others (.031).

\section{SUGGESTION:}

For a person to be considered emotionally intelligent they should be able to:

$>$ Recognize and manage their emotions.

$>$ Quickly reduce their own stress levels.

$>$ Confidently resolve any conflicts in a positive manner.

$>$ Develop some mastery over non verbal communication.

$>$ Using humour when dealing with the difficulties in life.

$>$ Gender can influence individual self- awareness because a male may value their skills and abilities much better than a woman or the other way round. and this affect what types of jobs they go for.

$>$ The research shows that older people are slightly more likely to be higher in emotional intelligence. The finding suggests emotional intelligence is a developing ability, it is likely that accumulated life experiences contribute to EQ.

$>$ This research confirmed that age influences the social awareness of the new generation employees. on the contrary, it may pinpoint age intervals in which developing and increasing emotional intelligence abilities should take precedence. This information would be valuable to managers in the hiring process, as well as in employee development and training programs.

$>$ Based on the findings from the study, it is recommended that managers and trainers should encourage the development of a strong achievement motivation in the new generation employees through the provision of appropriate counselling intervention programmes and enabling environment. by so doing, the performance of the new generation employees could be improved barring all other training-learning obstacles.

$>$ The research shows that education influences the social skills. if the employees are much more educated they would have a better social skill.

$>$ It is a reality that many employees are looking for employees who have some sort of postsecondary education. This education shows that they had a particular interest in a field that they wanted to progress in, and proves that they took additional classes that will allow them to achieve and progress in their desired field. Since most college students are focused on a particular career pathway, it gives a much more in-depth look into a subject that may not have been covered in earlier years of schooling. so education influences the social skills

\section{Conclusion}

Emotional intelligence is involved in the capacity to perceive emotions, assimilate emotion related feelings, understand the information of those emotions, and manage them. Organizations and the conscious, achievement-oriented managers needs a high rate of "emotional intelligence" to be successful. In conclusion, there are currently many academic studies about emotional intelligence. Each generation grew up in a different time with different values. Managing this gap can be quite a challenge if you see every employee through the eyes of your generation. Other people of different generations, genders, management status, backgrounds, and cultures who have different values, ideas, ways of communicating and getting things. One of the most important management challenge is to manage generation $\mathrm{X}$ and $Y$ together. With the generational differences in work life, organizations and leaders must have some idea of how to relate to different generations. So, the researches defining specific differences between these generations are important to overcome this challenge. This study aimed to analyze the emotional intelligence according to generation, and as a result, it is proved that emotional intelligence does not differ between generation $\mathrm{X}$ and $\mathrm{Y}$. Each generation has different values and frame of mind but emotional intelligence is unconnected and common variable therefore emotional intelligence should be evaluated independently of generations. 


\section{References:}

1. C.R Kothari, Research Methodology methods and technique, Second revised Edition, New age International publishers

2. K Aswathappa ,Human resource management Tata McGraw-Hill Company Limited, Fifth Edition

3. Steven L. McShane, Organisational Behaviour Tata McGraw-Hill company limited, page no:129131,Third Edition
4. Bloom, F., Nelson, C.A. and Lazerson, A. (2001). Brain, Mind and Behavior, Third Edition. Worth Publisher.

5. Chan, D. W. (2006). Emotional Intelligence And Components Of Burnout Among Chinese Secondary School Teachers In Hong Kong. Teaching and Teacher Education, 22(8): 10421054

6. Goleman, D. (1998). Working With Emotional Intelligence. Bantam Books, New York.

7. Spielberger, C. D. (2004). The Encyclopedia of Applied Psychology. Elsevier, Oxford, UK.

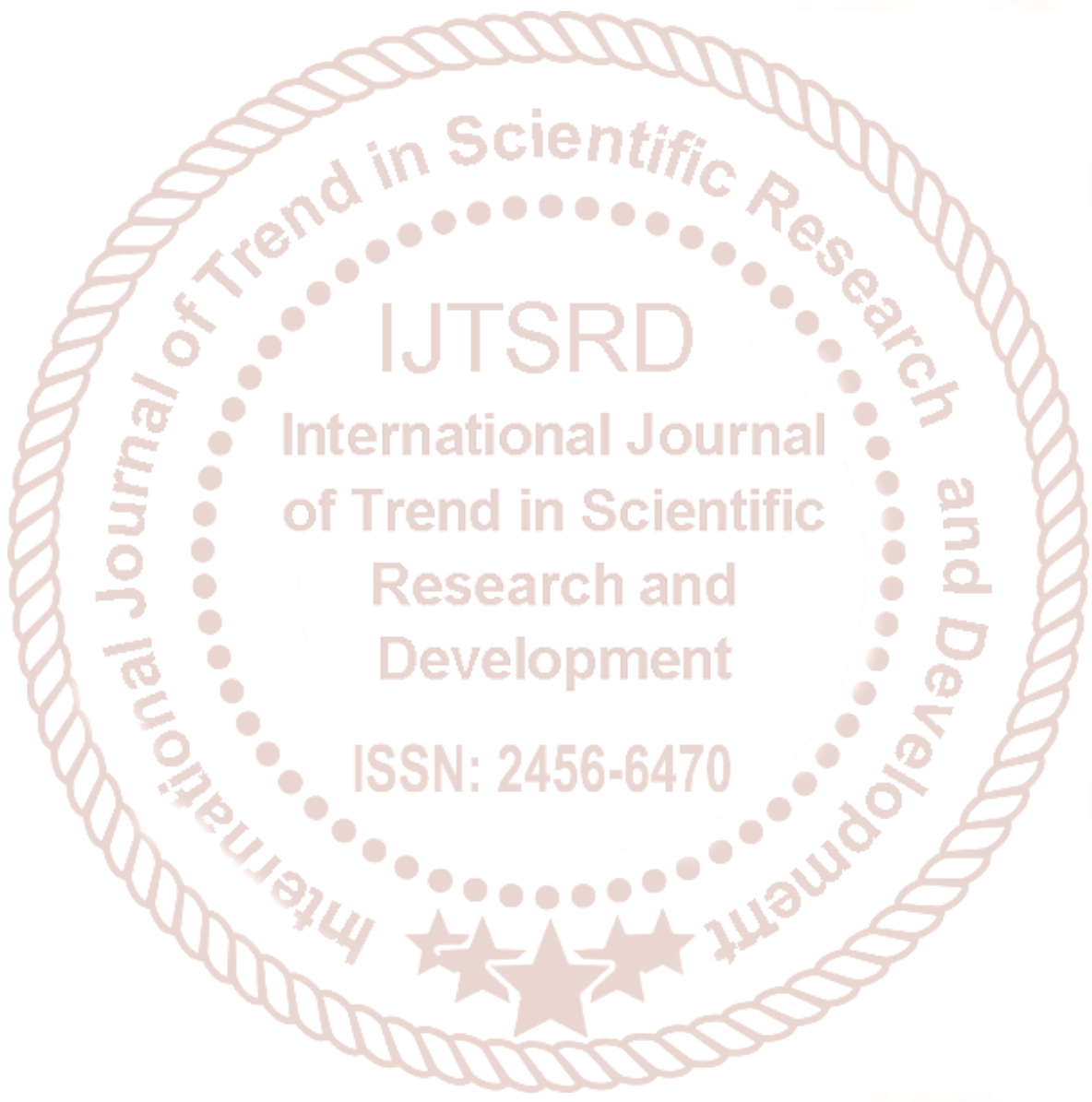

